University of Nebraska - Lincoln

DigitalCommons@University of Nebraska - Lincoln

1983

\title{
Survival of Mallard Broods in South-Central North Dakota
}

Larry Talent

Robert Jarvis

Gary Krapu

USGS Northern Prairie Wildlife Research Center, gkrapu@usgs.gov

Follow this and additional works at: https://digitalcommons.unl.edu/usgsnpwrc

Part of the Other International and Area Studies Commons

Talent, Larry; Jarvis, Robert; and Krapu, Gary, "Survival of Mallard Broods in South-Central North Dakota" (1983). USGS Northern Prairie Wildlife Research Center. 64.

https://digitalcommons.unl.edu/usgsnpwrc/64

This Article is brought to you for free and open access by the US Geological Survey at DigitalCommons@University of Nebraska - Lincoln. It has been accepted for inclusion in USGS Northern Prairie Wildlife Research Center by an authorized administrator of DigitalCommons@University of Nebraska - Lincoln. 


\title{
SURVIVAL OF MALLARD BROODS IN SOUTH-CENTRAL NORTH DAKOTA
}

\author{
LARRY G. TALENT \\ ROBERT L. JARVIS \\ AND \\ GARY L. KRAPU
}

\begin{abstract}
Survival characteristics of 25 broods of Mallards (Anas platyrhynchos) were determined on a study area in the Missouri Coteau of south-central North Dakota in 1976-1977. Radio-equipped Mallard hens fledged at least one duckling in 7 of $16(44 \%)$ broods produced in 1976, 5 of $9(55 \%)$ in 1977 , and 12 of $25(48 \%)$ for both years combined. Of the 13 broods in which all young were lost, $11(85 \%)$ were lost within the first two weeks after hatching. All losses of entire broods occurred in wetlands; few ducklings and no entire broods were lost during overland travel. Predation by mink (Mustela vison) was apparently the principal cause of duckling mortality.
\end{abstract}

The magnitude and pattern of brood mortality are key factors in the reproductive ecology of waterfowl. Measurement of brood survival is essential for calculating recruitment from nesting data (Cowardin and Johnson 1979). Yet, survival and mortality patterns during the prefledging period are poorly understood.

Most duckling mortality in Mallards (Anas platyrhynchos) occurs before young are three weeks old (Dzubin and Gollop 1972, Ball et al. 1975), but the specific mortality factors of ducklings are largely unknown. Predation, accidents, and losses due to scattering or exhaustion are often cited as potential agents of mortality, but little direct evidence has been presented in the literature. Some workers have suggested that overland travel is particularly hazardous to survival of ducklings (Bellrose 1953, Keith 1961, Odum 1970, Dzubin and Gollop 1972). However, Evans and Black (1956) found no evidence that mobile broods suffered more mortality than sedentary broods in prairie wetland habitat.

This paper describes survival characteristics of Mallard broods on a study area in southcentral North Dakota as determined by radio telemetry and observation. To identify factors contributing to duckling mortality, we studied the effects of overland movement, predation, and hen-brood bonds on the survival of Mallard broods.

\section{STUDY AREA AND METHODS}

The study area in south-central North Dakota encompassed five tracts in Stutsman County. The largest tract $\left(93.2 \mathrm{~km}^{2}\right)$, referred to as the Medina Study Area, was $9.6 \mathrm{~km}$ south of Medina. This site was characteristic of the Missouri Coteau with moderately rolling glacial moraine, and from 2 to 14 wetland basins per square kilometer. The $41.4-\mathrm{km}^{2}$ central part of the area, where most radio tracking and observations took place, contained 10\% ephemeral wetlands, $33 \%$ temporary wetlands, $35 \%$ seasonal wetlands, and $15 \%$ semipermanent wetlands (Stewart and Kantrud 1971). The remaining wetlands were three permanent lakes of over 20 ha and several dugouts and fens. Land was principally used for livestock and small grain farming; about $40 \%$ of the uplands was in pasture and forage crops and $60 \%$ was cultivated. The second tract $\left(2.61 \mathrm{~km}^{2}\right)$ was a federally-owned Waterfowl Production Area (WPA), $6.4 \mathrm{~km}$ northwest of Medina. On this area, $16 \%$ of the wetland basins was seasonal and $84 \%$ was semipermanent. About $50 \%$ of the upland was cultivated or in forage crops and $50 \%$ was in native mixed-grass prairie or idle cover. During drought conditions in 1977, we also studied broods on three other WPA's about $14 \mathrm{~km}$ east of Medina. The third and fourth tracts were primarily in federal ownership as WPA's and contained single semipermanent wetlands of 181 and 22 ha, respectively. The fifth was a WPA of 180 ha containing 26 ha of wetland habitat. Uplands on those three tracts were in native prairie or a planted mixture of grasses and legumes.

Mallard hens were captured on nests with remote-controlled traps (Shaiffer and Krapu 1978) during 1976 and 1977 at about 20 days into incubation. Each hen was fitted with a back-mounted radio pack weighing about 25 $\mathrm{g}$ and similar to that described by Dwyer (1972). The location of each radio-equipped brood hen was plotted one to eight times each day and night. Locations were determined by triangulation from known positions with hand-held 
and vehicle-mounted receiving equipment. The number of ducklings per brood was determined immediately after all overland moves, when feasible, and regularly thereafter when disturbing the brood could be avoided. However, because Mallard broods prefer dense cover in wetlands (Talent et al. 1982), determination of brood size was difficult, especially after ducklings were about one week old. Thus, we concentrated our efforts on determining when and where loss of entire broods occurred.

In addition to studying wild broods, we monitored the fate of radio-marked, penreared, wild-stock ducklings and broods after their release into natural wetlands on the study area. In 1976, 16 pen-reared wild Mallard ducklings were each equipped with a backmounted radio package weighing about $5 \mathrm{~g}$ and similar to that described by Sayre et al. (1981). For ducklings older than two weeks, glue was supplemented with a loop harness of nylon line that extended from each side of the transmitter, around the wings, and was tied on the duckling's abdomen in front of the legs (Coon et al. 1976). These ducklings were released in wetlands during June and July in order to identify predators and to evaluate the effects of predation on duckling survival. In 1977, nine pen-reared, wild-stock Mallard hens were equipped with radio packs and released with their broods in wetlands during June and July in order to evaluate survival of broods in semipermanent wetlands during drought. Both radio-equipped pen-reared ducklings and hens with broods were monitored one to eight times daily to determine survival time and to identify causes of mortality.

\section{RESULTS}

\section{BROOD SURVIVAL ESTIMATES}

Estimates of brood survival for radio-equipped wild Mallard hens did not differ significantly between 1976 and $1977\left(\chi^{2}=0.32,1 \mathrm{df}, P>\right.$ 0.05 ). In 1976,7 of 16 hens with broods fledged at least one duckling and in 1977, 5 of 9 hens with broods fledged one or more young. Combined success for 1976 and 1977 was $48 \%$.

The 25 wild hens hatched 171 ducklings $(\bar{x}=6.84$ /brood). Thirteen of the hens, with a combined total of 76 young $(\bar{x}=5.85 /$ brood), lost their entire broods. Eighty-five percent of total brood mortality occurred within two weeks after the young hatched (Fig. 1). The 12 hens that fledged young hatched a total of 95 ducklings $(\bar{x}=7.92 /$ brood $)$. Initial brood size was not significantly different $(t=1.99,23 \mathrm{df}$, $P>0.05$ ) between hens that fledged young and those that lost their broods.

Brood size of only 4 of the 12 hens that

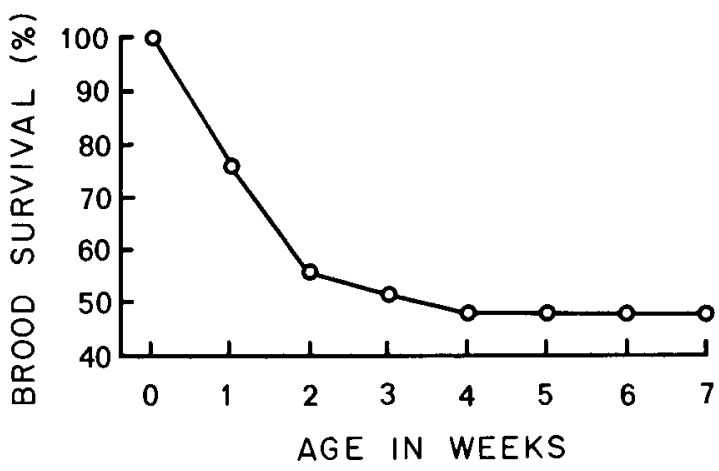

FIGURE 1. Weekly survival percentages of 25 radiomarked Mallard broods in south-central North Dakota, 1976-1977.

fledged young could be determined at time of fledging. Brood size of these hens averaged 5.0 young, which may be typical of prairie nesting Mallards; previous studies have reported brood size at flight stage of about five or six (Rienecker and Anderson 1960, Keith 1961, Moyle 1964, Dzubin and Gollop 1972). Assuming that each of the 12 successful hens fledged 5 young, then 35 ducklings were lost $(\bar{x}=2.92$ / brood) from these broods. Thus, Mallard rearing success of ducklings, including attrition and total-brood mortality, was about 35\% (60/171). Of the total number of ducklings produced, about $65 \%(111 / 171)$ were lost and over $68 \%$ (76/111) of all duckling mortality resulted from the loss of entire broods.

Over $60 \%$ of the Mallard nests found on the study area were in marshes (Krapu et al. 1979). Brood survival was not significantly different, however, between broods hatched in nests located over water in marshes and those hatched in nests in upland habitat $\left(\chi^{2}=0.10,1 \mathrm{df}, P>\right.$ 0.05 ). Nine of the 18 broods hatched from nests located over water survived and 3 of 7 broods hatched from nests in upland habitat survived. Upland nests were an average of 140 $\mathrm{m}$ from the first wetland used by the broods.

\section{OVERLAND MOVEMENT}

Several researchers have surmised that young ducklings were most vulnerable to mortality during overland movement (Bellrose 1953, Keith 1961, Odum 1970, Dzubin and Gollop 1972). We found no evidence, however, that Mallard duckling mortality was greater in broods that traveled overland among wetlands than in broods remaining on one wetland $\left(\chi^{2}=\right.$ $0.05,1 \mathrm{df}, P>0.05)$. Of the 25 radio-marked wild broods, 11 were sedentary on one wetland until death or fledging whereas 14 were mobile and utilized from 2 to 10 wetlands. Loss of entire broods occurred in six of the sedentary and seven of the mobile broods. No mobile 
broods were lost while traveling between wetlands and no entire broods were lost while traveling overland from the nest to water.

Cumulative overland travel was not positively related to the loss of all ducklings in mobile broods. Of seven broods that traveled $1.5 \mathrm{~km}$ or more overland, five fledged at least one duckling; of the seven broods making overland moves totaling $1.5 \mathrm{~km}$ or less, only two survived to fledge one or more young. The greatest cumulative overland movement was made by the brood of a yearling hen; this brood traveled $5.6 \mathrm{~km}$ and passed through 10 different wetlands before the young were eight days old and only one of eight ducklings was lost. If exhaustion, exposure, and scattering of ducklings took place at a significant level during overland moves, then several short overland moves among wetlands over a two-week period would logically seem less stressful to young ducklings than one overland move of equal distance. The brood making the longest single overland move $(2.4 \mathrm{~km})$ lost only one of seven ducklings. Thus, during our study, overland travel was not the major mortality factor of Mallard ducklings.

\section{PREDATION}

All losses of entire broods occurred in wetland habitat and predation appeared to be the principal cause. To evaluate the effects of predation on wild broods in 1976, we concentrated our efforts on the Medina Study Area. All ducklings in 8 of the 12 radio-marked wild broods produced on this area were lost before they were two weeks old. We found numerous partially consumed carcasses of ducklings around mink (Mustela vison) dens and also observed a mink feeding on a Mallard hen. Six of the eight broods were lost on semipermanent wetlands and two were lost on seasonal wetlands.

Data from pen-reared ducklings supported our contention that predation was the probable cause of the loss of most radio-marked wild broods. We placed 12 radio-equipped penreared ducklings on the wetlands where the eight wild radio-marked broods were lost. Two ducklings placed on seasonal wetlands survived, whereas 10 ducklings placed on semipermanent wetlands were all lost within two days, apparently from predation. Duckling remains and radio packs were found near shore in shallow water or on shore along trails at mink dens. We also placed four pen-reared radio-equipped ducklings on two wetlands where radio-marked wild broods were surviving to identify potential predators; none was killed by predators and a search of the shoreline of these wetlands revealed no mink dens. Thus, in 1976 predation on pen-reared duck- lings occurred only on wetlands containing mink dens.

Owing to a severe drought in 1977 , only semipermanent and permanent wetlands held water. Only $10 \%$ of the wetland basins on the Medina Study Area contained water on 1 May; their use by radio-marked broods was restricted to semipermanent wetlands (Talent et al. 1982). To study the effects of predation on entire broods, we released nine radio-equipped pen-reared hens with broods in semipermanent wetlands where wild broods had been observed. After two weeks, seven of the nine broods (62 ducklings) and two hens were lost; mink predation was apparently the principal cause of mortality. Mallard duckling remains were found scattered around entrances to mink dens and the two hens were killed by mink. Although the pen-reared broods and ducklings released on the study area were probably more susceptible to predation than wild Mallard ducklings (Schladweiler 1969, Sargeant et al. 1973), our data suggest that predation by mink was the major cause of mortality of wild ducklings on our study area.

\section{HEN-BROOD BOND}

The 12 radio-equipped wild Mallard hens that fledged young stayed with their broods for an average of 48.8 days and no broods younger than 44 days old were abandoned. Females abandoned their broods gradually: during the last week of brood-rearing, females typically left their broods for longer periods each day until abandonment was complete. Although early female abandonment of broods may contribute to duckling mortality, we saw no evidence that early abandonment contributed to total brood loss. Female dabbling ducks usually remain with their ducklings until near fledging (Evans et al. 1952), and Ball et al. (1975) found that Mallard hens in north-central Minnesota remained with their broods for an average of 50.7 days.

Eight of the 25 radio-equipped wild hens were observed to regularly leave their broods and feed in grain fields up to $1.6 \mathrm{~km}$ away. Most feeding trips lasted less than $2 \mathrm{~h}$ and were usually initiated after ducklings were over two weeks old. Two females, however, began to feed in grain fields when their broods were less than three days old. These individuals fed away from the broods daily at sunset, even during cold, rainy weather; both broods were lost within one week after hatching. We placed radio-equipped pen-reared ducklings in the wetlands where the two broods were lost to determine if predators were present. The released ducklings were not lost to predators and a search of shorelines revealed no mink dens, 
suggesting that the wild ducklings died from exposure (Seymour 1982).

\section{DISCUSSION}

Although radio-equipped hens possibly were less efficient at rearing young than unmarked females, Ball et al. (1975) found no significant difference in the size of broods reared by radioequipped and unmarked hens. Therefore, we assume that the survival patterns of radiomarked broods were not significantly different from those of unmarked broods.

Loss of entire broods accounted for a greater proportion of total duckling losses than simple attrition within successful broods. All mortality of entire broods occurred in wetlands, and we could account for the loss of only a few ducklings during overland travel. Ball et al. (1975) reported a negative correlation between number of surviving ducklings and cumulative distance of overland travel, suggesting that some attrition within broods occurs during travel among wetlands. Our data, however, indicate that moving overland may not contribute significantly to the loss of entire broods. Although some ducklings are lost during movements among wetlands, the magnitude of those losses probably depends on local conditions such as topography, vegetation, predator density, and weather.

We noted no loss of entire broods during their initial move from the nest to water. The first overland trip of a brood is thought to be particularly hazardous. Dzubin and Gollop (1972:130) estimated that survival rate of newly hatched broods from nest to water was only $48 \%$. We suspect, however, that their estimate of loss is biased too high because they did not monitor broods daily. In order to determine if brood mortality occurs during overland travel, individually marked brood hens must be observed immediately after they arrive on a wetland. Most total brood mortality on our study area occurred within $24 \mathrm{~h}$ after a brood moved onto a wetland.

Nearly all brood mortality occurred before ducklings were two weeks old, and predation was probably the principal cause of the mortality. Duckling survival may have been enhanced after they were two weeks old because of growth, development, and experience, but by this time most Mallard broods had already reached secure brooding areas. On our study area, secure brooding areas were usually wetlands that did not have mink dens. Most movement of broods occurred when young were less than two weeks old, and any broods arriving on a relatively small $(<12 \mathrm{ha})$ wetland inhabited by mink either immediately continued their travels or were quickly killed. Thus, the apparent enhanced survival of broods over two weeks old was probably due as much to securing safe habitat as to growth and development.

Our assessment that mink are major predators of wild duck broods enlarges the results of other studies. Bailey (1926) suggested that mink were important predators of waterfowl; recent studies in North Dakota indicate that mink prey heavily on waterfowl and probably significantly influence waterfowl production in some marshes (Eberhardt 1973, Sargeant et al. 1973, Eberhardt and Sargeant 1977). On our study area, mink predation occurred largely on semipermanent wetlands. These areas are probably more suitable as mink foraging and denning areas than seasonal wetlands. Although the pattern and magnitude of duckling mortality probably vary during wet-drought cycles in the prairies (Talent 1980:71), mink predation may affect the average number of young fledged per female.

Eight of 25 (32\%) radio-equipped wild hens in our study periodically left their broods and fed in grain fields. We detected no negative effects of this behavior on six broods, but all ducklings in two broods apparently died of exposure as a result of the hens' absence during inclement weather. Both lost broods were hatched by adult (at least two years old) hens during mid-June and were probably from renests (first sightings of broods in 1976 and 1977 were both on 26 May). The physical condition of these hens possibly affected their attentiveness to broods. Weight loss of female Mallards in North Dakota averages $25 \%$ between prelaying and late incubation, and hens do not accumulate substantial lipid reserves before renesting (Krapu 1981). Presumably, some brood hens with low lipid reserves are physiologically stressed by one or more renesting attempts and, to replenish their lipid reserves, may periodically leave their broods and feed on high-energy waste grain in fields. Although such behavior may sometimes increase duckling mortality, it probably enhances a female's fitness by increasing her chances of surviving to rear a larger number of offspring during her lifetime.

Substantial loss of entire broods has two important implications for waterfowl biologists. First, estimates of the average number of ducklings fledged per female, when the zero size class (broods with all ducklings lost) is ignored, will be strongly biased. In our study, failure to account for loss of entire broods would have caused us to overestimate the average number of young fledged per female by over $100 \%$. Similarly, Ball et al. (1975), Reed (1975), and Ringelman and Longcore (1982) found that 
failure to account for loss of entire duck broods resulted in significantly overestimating recruitment on their study areas. Secondly, a high loss of entire broods may confound nest success rates as an index to recruitment of fledged young. In view of the large proportion of entire broods lost during our study, the relationship between nest success rates and brood survival should be investigated to determine if rates of loss of entire broods are additive, compensatory, or unrelated to rates of nest success.

\section{ACKNOWLEDGMENTS}

We thank L. M. Cowardin, J. A. Crawford, H. F. Duebbert, and A. B. Sargeant for critically reviewing the manuscript; D. G. Jorde and L. Kludt for assisting in the study; S. D. Becker and R. K. Green for helping find Mallard nests; and A. D. Kruse for providing additional manpower and equipment for upland nest-searching. The study was supported by the Northern Prairie Wildlife Research Center (Contract No. 14-16-0003-2038) and conducted under the auspices of the Oregon Cooperative Wildlife Research Unit: Oregon Department of Fish and Wildlife, Oregon State University, U.S. Fish and Wildlife Service and Wildlife Management Institute cooperating. Oregon State University Agricultural Experiment Station Technical Paper No. 6260.

\section{LITERATURE CITED}

BAILEY, V. 1926. A biological survey of North Dakota. North Am. Fauna No. 49.

Ball, I. J., D. S. Gilmer, L. M. Cowardin, and J. H. RiechmanN, 1975. Survival of Wood Duck and Mallard broods in north-central Minnesota. J. Wildl. Manage. 39:776-780.

Bellrose, F. C. 1953. Housing for Wood Ducks. Ill. Nat. Hist. Surv. Circ. No. 45.

Coon, R. A., P. D. Caldwell, and G. L. Storm. 1976. Some characteristics of fall migration of female Woodcock. J. Wildl. Manage. 40:91-95.

Cowardin, L. M., and D. H. Johnson. 1979. Mathematics and Mallard management. J. Wildl. Manage. 43:18-35.

DWYER, T. J. 1972. An adjustable radio-package for ducks. Bird-Banding 43:282-284.

Dzubin, A., AND J. B. Gollop. 1972. Aspects of Mallard breeding ecology in Canadian parkland and grassland, p. 113-152. In Population ecology of migratory birds. U.S. Fish. and Wildl. Serv. Res. Rep. No. 2.

EBERHARDT, R. T. 1973. Some aspects of mink-waterfowl relationships on prairie wetlands. Prairie Nat. 5: 17-19.

Eberhardt, L. E., and A. B. Sargeant, 1977. Mink predation on prairie marshes during the waterfowl breeding season, p. 33-43. In Proceedings of the 1975 predator symposium. Mont. For. Conserv. Exp. Stn. Spec. Publ.

Evans, C. D., AND K. E. Black. 1956. Duck production studies on the prairie potholes of South Dakota. U.S. Fish Wildl. Serv., Spec. Sci. Rep. Wildl. No. 32.

Evans, C. D., A. S. Hawkins, and W. H. Marshall.
1952. Movements of waterfowl broods in Manitoba. U.S. Fish Wildl. Serv., Spec. Sci. Rep. Wildl. No. 16. KeITH, L. B. 1961. A study of waterfowl ecology on small impoundments in southeastern Alberta. Wildl. Monogr. No. 6.

KRAPU, G. L. 1981. The role of nutrient reserves in Mallard production. Auk 98:29-38.

Krapu, G. L., L. G. Talent, and T. J. Dwyer. 1979. Marsh nesting by Mallards. Wildl. Soc. Bull. 7:104110 .

Moyle, J. B. 1964. A resume of the four studies, p. 825. In J. B. Moyle [ed.], Ducks and land-use in Minnesota. Minn. Dep. Conserv., Tech. Bull. No. 8.

ODum, R. R. 1970. Nest box production and brood survival of Wood Ducks on the Piedmont National Wildlife Refuge 1969. Proc. Southeast. Assoc. Game Fish Comm. 24:108-117.

ReED, A. 1975. Reproductive output of Black Ducks in the St. Lawrence estuary. J. Wildl. Manage. 39:243255.

Rienecker, W. C., And W. Anderson. 1960. A waterfowl nesting study on Tule Lake and Lower Klamath National Wildlife Refuges, 1957. Calif. Fish Game 46:481-506.

Ringelman, J. K., AND J. R. LongCore. 1982. Survival of juvenile Black Ducks during brood rearing. J. Wildl. Manage. 46:622-628.

Sargeant, A. B., G. A. Swanson, and H. A. Doty. 1973. Selective predation by mink, Mustela vison, on waterfowl. Am. Midl. Nat. 89:208-214.

Sayre, M. W., T. S. Baskett, and P. B. Blenden. 1981. Effects of radio-tagging on breeding behavior of Mourning Doves. J. Wildl. Manage. 45:428-434.

Schladweiler, J. L. 1969. Survival and behavior of hand-reared Mallards (Anas platyrhynchos) released in the wild. M.Sc. thesis, Univ. Minnesota, Minneapolis.

SEYmour, N. R. 1982. Mortality of duckling attributed to separation from mother and subsequent protracted exposure to low ambient temperature. Auk 99:383384.

Shaiffer, C. W., and G. L. Krapu. 1978. A remotecontrolled system for capturing nesting waterfowl. J. Wildl. Manage. 42:668-669.

Stewart, R. E., and H. A. Kantrud. 1971. Classification of natural ponds and lakes in the glaciated prairie region. U.S. Fish and Wildl. Serv. Resour. Publ. No. 92.

TALENT, L. G. 1980. Ecology of breeding Mallards: nest parasitism; brood survival; and, habitat utilization. Ph.D. diss., Oregon State Univ., Corvallis.

Talent, L. G., G. L. Krapu, and R. L. Jarvis. 1982. Habitat use by Mallard broods in south central North Dakota. J. Wildl. Manage. 46:629-635.

Oregon Cooperative Wildlife Research Unit, Oregon State University, Corvallis, Oregon 97331. Present address: Department of Zoology, Oklahoma State University, Stillwater, Oklahoma 74078. Address of second author: Department of Fisheries and Wildlife, Oregon State University, Corvallis, Oregon 97331. Address of third author: U.S. Fish and Wildlife Service, Northern Prairie Wildife Research Center, Jamestown, North Dakota 58401. Received 28 November 1981. Final acceptance 7 September 1982. 